\title{
Muttarak's Study Design Cannot Support the Link Between the Body-Positive Movement and Overweight or Obesity
}

Citation for published version (APA):

Alleva, J. M., \& Tylka, T. L. (2018). Muttarak's Study Design Cannot Support the Link Between the BodyPositive Movement and Overweight or Obesity. Obesity, 26(10), 1527-1527. https://doi.org/10.1002/oby.22281

Document status and date:

Published: 01/10/2018

DOI:

10.1002/oby.22281

Document Version:

Publisher's PDF, also known as Version of record

Document license:

Taverne

Please check the document version of this publication:

- A submitted manuscript is the version of the article upon submission and before peer-review. There can be important differences between the submitted version and the official published version of record.

People interested in the research are advised to contact the author for the final version of the publication, or visit the DOI to the publisher's website.

- The final author version and the galley proof are versions of the publication after peer review.

- The final published version features the final layout of the paper including the volume, issue and page numbers.

Link to publication

\footnotetext{
General rights rights.

- You may freely distribute the URL identifying the publication in the public portal. please follow below link for the End User Agreement:

www.umlib.nl/taverne-license

Take down policy

If you believe that this document breaches copyright please contact us at:

repository@maastrichtuniversity.nl

providing details and we will investigate your claim.
}

Copyright and moral rights for the publications made accessible in the public portal are retained by the authors and/or other copyright owners and it is a condition of accessing publications that users recognise and abide by the legal requirements associated with these

- Users may download and print one copy of any publication from the public portal for the purpose of private study or research.

- You may not further distribute the material or use it for any profit-making activity or commercial gain

If the publication is distributed under the terms of Article $25 \mathrm{fa}$ of the Dutch Copyright Act, indicated by the "Taverne" license above, 
Muttarak's Study Design Cannot Support the Link Between the Body-Positive Movement and Overweight or Obesity

\section{Jessica M. Alleva ${ }^{1}$ (D) and Tracy L. Tylka ${ }^{2}$}

TO THE EDITOR: We raise a substantial concern with a recent publication in Obesity (1). Here, we focus on the implied causal link between the body-positive movement and overweight and/or obesity. For concerns about an additional problematic aspect of this article, which is that perceiving weight accurately will lead to improved health, see Stewart (2).

Muttarak (1) compared self-report data collected between 1997 and 2015 concerning people's BMI, whether they perceived themselves as "about the right weight," "too heavy," "too light," or "not sure," and whether they reported "currently trying to lose weight," "trying to gain weight," or "not trying to change weight." From 1997 to 2015 , a larger proportion of adults classified as having overweight and/or obesity perceived themselves to be "about the right weight" rather than "too heavy." Those who underestimated their weight were less likely to report trying to lose weight.

Muttarak's (1) study design was correlational. She did not include a measure of the body-positive movement. For these two reasons, she cannot determine the body-positive movement's impact on weight misperception and weight-change efforts. Unfortunately,
Muttarak (1) erroneously made this causal claim. For example, she states that the availability of "plus-size" clothing likely "contributed to the normalization of stigma associated with overweight and obesity" (page 1125) and that the body-positive movement "can potentially undermine the recognition of being overweight and its health consequences" (page 1125) (1). Yet these statements extend beyond the conclusions allowable by her study design. To support her causal claims, she would have had to conduct experimental research measuring, for example, whether exposure to body-positive imagery prompts weight misperception and weight-change efforts compared with a control group that is not exposed to this imagery.

Also concerning is that Muttarak's (1) cited references are often either unrelated to her claims or have misinterpreted the referenced study's findings. To demonstrate, Muttarak (1) noted that "although purchasing clothes with smaller size labels helps promote a positive self-related mental imagery and self-esteem (3), vanity sizing can potentially lead to the misperception of weight status and consequently undermine action to reduce weight (4)." This statement is misleading as, in Aydinoglu and Krishna (3), participants did not actually purchase clothing; they were merely asked to imagine it, and its impact on weight misperception and weight-loss attempts were not assessed. Furthermore, Duncan and colleagues (4) merely investigated the correlations between weight underestimation, weight-loss attempts, and physical activity; exposure to plus- or vanity-sized clothing was not assessed.

Deleterious consequences result from misleading scientific reporting. Muttarak's institute published a press release, titled "Normalisation of 'plus-size' risks hidden danger of obesity" (5). Numerous media published similar headlines. To reiterate, Muttarak (1) did not test this causal link, and her data cannot be used to support it. Most people do not investigate the scientific research behind the headlines. Therefore, it is our responsibility as scholars to accurately represent our work and its limitations and, as reviewers and editors, to not publish work that makes causal assumptions using correlational designs with variables that are not even measured. $\mathbf{O}$

\section{(C) 2018 The Obesity Society}

\section{References}

1. Muttarak R. Normalization of plus size and the danger of unseen overweight and obesity in England. Obesity (Silver Spring) 2018;26:1125-1129.

2. Stewart TM. Why thinking we're fat won't help us improve our health: finding the middle ground. Obesity (Silver Spring) 2018;26:1115-1116.

3. Aydinoglu NZ, Krishna A. Imagining thin: why vanity sizing works. J Consum Psychol 2012;22:565-572.

4. Duncan DT, Wolin KY, Scharoun-Lee M, Ding EL, Warner ET, Bennett GG. Does perception equal reality? Weight misperception in relation to weight-related attitudes and behaviors among overweight and obese US adults. Int J Behav Nutr Phys Act 2011;8:20. doi:10.1186/1479-5868-8-20.

5. University of East Anglia. Normalisation of "plussize" risks hidden danger of obesity [press release]. https://www.uea.ac.uk/about/-/normalisation-ofplus-size-risks-hidden-danger-of-obesity-studyfinds. Published June 22, 2018. Accessed June 27, 2018.

\footnotetext{
${ }^{1}$ Department of Clinical Psychological Science, Maastricht University, The Netherlands. ${ }^{2}$ Department of Psychology, Ohio State University, Marion, Ohio, USA. Correspondence: Jessica M. Alleva (jessica.alleva@maastrichtuniversity.nl)
}

Disclosure: The authors declared no conflict of interest.

doi:10.1002/oby.22281 